DOI: 10.32089/WBH.PHW.2019.4(270).0006

orcid.org/0000-0002-9372-9292

MichaŁ KozŁowski

\title{
Jerzy Giedlroyc i czasopisma wojskowe PRL
}

Jerzy Giedroyc podobno miał stwierdzić, że jego ulubionym krajowym periodykiem jest „Wojskowy Przegląd Historyczny”. Przytoczona opinia pochodzi z jednego z wielu wywiadów, jakich udzielił po 1989 r. Zwracał na niego uwagę historykom i wojskowym, z którymi korespondował. W liście do gen. Józefa Jaklicza z 17 grudnia 1971 r. pisał: „Nie wiem czy Pan obserwuje «Wojskowy Przegląd Historyczny». Od pewnego czasu można w nim znaleźć interesujące materiały"1.

Od wielu lat trwa proces wydawania listów Jerzego Giedroycia i jego współpracowników piszących do „Kultury” i „Zeszytów Historycznych”. Wielotomowe wydanie korespondencji Giedroycia stawia pytanie, czy wszystkie wydane tomy są potrzebne. Książę z Maisons-Lafitte był szczery w listach do zaledwie kilkunastu najbliższych współpracowników. Duża część jego korespondencji to typowe redakcyjne „rozkazy dzienne”. Nie wnosi ona za wiele do naszej wiedzy².

Czasopisma wojskowe z PRL napływały do Instytutu Literackiego różnymi drogami. W latach 1957-1964 trwała wymiana z Biblioteką Naukową Akademii Wojskowo-Politycznej/Wojskowej Akademii Politycznej (WAP). Początek współpracy datuje się na 28 marca 1957 r. Jerzy Giedroyc pisał, że dokłada starań, by „Kultura” przedostawała się do Polski i była czytana. Kierownik Biblioteki WAP prosił zaś redaktora o udzielenie bezpłatnej prenumeraty $^{3}$. 13 kwietnia 1957 r. Giedroyc prosił o prenumeratę pisma

\footnotetext{
1 Jestem wdzięczny dr. hab. Sławomirowi M. Nowinowskiemu za tę informację.

2 W poszukiwaniu innej historii: antologia tekstów opublikowanych na łamach periodyków Instytutu Literackiego w Paryżu, red. R. Stobiecki, S. M. Nowinowski, współpr. A. Brzezińska, M. Przybysz, Łódź-Paryż 2015.

3 Archiwum Instytutu Literackiego, Korespondencja Redakcji, teczka 916, http://static. kulturaparyska.com/attachments/25/97/5e820cd09e101c897b88a29fe30b1a0fe481c03c.jpg (dostęp 24 X 2019).
} 
„Nowe Czasy”. W zamian obiecywał regularne dostawy „Kultury”4. W kolejnych listach Giedroyc sugerował pracownikom Biblioteki Naukowej sposoby na obejście obostrzeń cenzury, która uniemożliwiała krajowym instytucjom otrzymywanie czasopisma ${ }^{5}$. Dość szybko kierownik Biblioteki Naukowej wysyłał Jerzemu Giedroyciowi zamówione przez niego pozycje i złożył sprawozdania z rozmów na temat wysyłki książek do Maisons-Laffitte $\mathrm{z}$ rozmaitymi wydawnictwami ${ }^{6}$. Giedroyc był zainteresowany bardzo pismami: „Nowe Czasy” i „Wojsko Ludowe”. W liście z 7 lipca 1962 r. kierownik biblioteki WAP pisał: „Tak «Kultura», jak i książki przesyłane przez Panów bardzo nas interesują ze względu na ich wysoki poziom" ${ }^{\text {. Nie wia- }}$ domo, z jakich innych źródeł Instytut Literacki pozyskiwał czasopisma wojskowe. Faktem jest, że w zbiorach w Maisons-Laffitte znajduje się komplet numerów WPH. W latach 1996-1997 miała miejsce krótka korespondencja pomiędzy Jerzym Giedroyciem a „Wojskowym Przeglądem Historycznym”. Miała ona na celu uzupełnienie braków w bibliotece redaktora „Kultury”. Podstawą edycji są materiały archiwalne przechowywane w Archiwum Instytutu Literackiego (Korespondencja Redakcji - teka 922, k. 1-4).

4 Ibidem.

5 Ibidem.

6 Ibidem.

7 Ibidem.

8 Ibidem. 
24 września 1996

\section{[1]}

Szanowni Panowie.

Przy porządkowaniu naszej biblioteki stwierdziliśmy ogromne braki w rocznikach „Wojskowego Przeglądu Historycznego"

Mianowicie brakuje nam:

Rok 1988: 1/123, 3/125

1989: $2 / 128$

1992: 1/139 i następne.

Będziemy wdzięczni za uzupełnienie tych braków. Ma się rozumieć, koszta z tym związane jesteśmy gotowi pokryć.

Łączę wyrazy poważania Redaktor KULTUURY (Jerzy Giedroyc) 
Warszawa 21.10.1996

\section{Szanowny Panie Redaktorze!}

Serdecznie dziękuję za list z 24 września 1996 roku. Jestem zaskoczony brakami w zasobach Wojskowego Przeglądu Historycznego Instytutu Literackiego.

Jeszcze dziś - przekażę Pański list redaktorowi naczelnemu WPH, którym jest obecnie ppłk mgr Czesław Szafran ${ }^{9} \mathrm{z}$ nadzieją, że sprawa będzie załatwiona pozytywnie.

Przy okazji załączam aktualny adres redakcji:

00-950 Warszawa

ul. Grzybowska 77, p. 229

tel. 6821611,6822113

Z wyrazami szacunku

Dyrektor Biblioteki Wojskowej

płk doc. dr hab. Kazimierz Łastawski ${ }^{10,11}$

[Przepraszam, ale list otworzyłem dopiero po powrocie z urlopu]

9 Czesław Szafran (ur. 29 I 1948 w Kolbuszowej) - pułkownik, historyk. W WP od 1965, absolwent Oficerskiej Szkoły Łączności w Zegrzu (1968), pułkownik od 1998. W latach 19771998 pracownik Wojskowego Instytutu Historycznego, 1998-2002 zatrudniony na Akademii Obrony Narodowej (dalej: AON). Członek PZPR 1967-1990. Absolwent historii w Wojskowej Akademii Politycznej (1977). Doktorat w 2001 na AON („Organizacja i działalność Wojskowego Instytutu Historycznego w latach 1959-1997”; promotor Tadeusz Panecki; egzemplarz pracy jest niedostępny w archiwum i bibliotece Akademii Sztuki Wojennej). Zastępca redaktora „Wojskowego Przeglądu Historycznego" od nr 3/1985 do nr 1/1993, redaktor naczelny od nr 3/1993 do nr 4/1997. Centralne Archiwum Wojskowe Wojskowego Biura Historycznego (dalej: CAW-WBH), Kolekcja Teczek Akt Personalnych (dalej: TAP), sygn. 3056/2018/461, Akta personalne Czesława Szafrana, k. 1-180.

10 Kazimierz Łastawski (właśc. Kazimierz Łata, ur. 1 II 1942 w Zapasterniczu) - pułkownik, politolog, historyk stosunków międzynarodowych, bibliotekarz. W WP od 1960, absolwent Oficerskiej Szkoły Wojsk Zmechanizowanych we Wrocławiu (1963), pułkownik od 1985. Absolwent historii WAP (1971). Doktorat w 1976 na WAP („Koncepcje polityki zagranicznej Wielkiej Brytanii w latach 1945-1956”; promotor: J. Muszyński). W 1984 habilitacja na Wydziale Dziennikarstwa i Nauk Politycznych UW („Ruch socjaldemokratyczny wobec powojennego bezpieczeństwa Europy"). W latach 1973-1990 pracownik WAP. W latach 1986-1990 kierownik Katedry Historii Międzynarodowego Ruchu Robotniczego i Stosunków Międzynarodowych WAP. Członek PZPR 1963-1990. W latach 1990-1997 dyrektor Centralnej Biblioteki Wojskowej. Od 2004 kierownik Zakładu Europeistyki Instytutu Politologii UMK. CAW-WBH, TAP, sygn. 2045/06/353, Akta personalne Kazimierza Łastawskiego, k. 1-106.

11 Łastawski był od 1974 r. zaliczany do Funduszu Przyspieszonego Rozwoju istniejącego od lat siedemdziesiątych w ludowym Wojsku Polskim, funduszu inwestowania w perspektywiczne kadry. Grupa oficerów tego funduszu cieszyła się przywilejami finansowymi, miała zapewnioną możliwość szkoleń i szybką ścieżkę awansu. Fundusz miał czuwać nad ich przygotowaniem do roli dowódców. Typowania kadr zaliczanych do funduszu dokonywano podczas corocznych przeglądów kadrowych na wszystkich szczeblach dowodzenia od pułku 
[3]

Wojskowy Przegląd Historyczny

Redakcja

12.12.1996

Szanowny Panie Redaktorze,

Odpowiadając na Pański list, który nawiasem mówiąc dotarł do redakcji z dużym opóźnieniem, uprzejmie informuję, że przekazaliśmy panu dr. Markowi Krawczykowi ${ }^{12} \mathrm{w}$ Warszawie większość wyszczególnionych przez Pana archiwalnych [zeszytów] „Wojskowego Przeglądu Historycznego”. Pozostałe dwa numery /1/1988 i 3/1998/, którymi obecnie nasze archiwum nie dysponuje, postaramy się dostarczyć tą samą drogą w terminie późniejszym.

Oczywiście przekazane numery traktujemy jako gratisy.

Łączę wyrazy głębokiego szacunku Redaktor Naczelny Ppłk mgr Czesław Szafran

PS Dziękując za przesłane numery „Zeszytów Historycznych” pozwolę sobie wyrazić przekonanie, że byłoby dobrze zapoczątkować stałą wymianę bieżących numerów „Zeszytów Historycznych” i „Wojskowego Przeglądu Historycznego". Będę wdzięczny za Pańskie zdanie w tej sprawie.

wzwyż. Znaleźli się w nim oficerowie, będący członkami PZPR i lojalni wobec ZSRS; zob. Archiwum Wojskowe w Nowym Dworze Mazowieckim, Akta Wojskowej Akademii Politycznej im. Feliksa Dzierżyńskiego z lat 1951-1990, sygn. 172.1.3446, Edward Wojdat, „Badanie funkcjonowania Funduszu Przyspieszonego Rozwoju Kadry Oficerskiej (na przykładzie związku taktycznego w Marynarce Wojennej)", Warszawa 1974.

12 Marek Krawczyk (ur. 25 IV 1956 w Warszawie - zm. 25 IV 2012 w Warszawie) - wydawca, działacz opozycji demokratycznej. Absolwent Liceum Ogólnokształcącego im. Hugona Kołłątaja w Warszawie (1975). W latach 1976-1980 pracował m.in. w Składnicy Księgarskiej, Polska Agencja Informacyjna Interpress i Ośrodku Rozpowszechniania Wydawnictw Naukowych PAN. Od 1979 kolporter i składacz książek niezależnych wydawnictw NOWa i „Głos”. W 1981 koordynator zaopatrzenia dla Głosu, pracownik „Tygodnika Solidarność”. W okresie stanu wojennego współpracownik „Wiadomości”. 5 I 1982 aresztowany i 15 II 1982 skazany w trybie doraźnym wyrokiem Sądu Warszawskiego Okręgu Wojskowego na 2 lata więzienia w zawieszeniu na 4 lata. 23 III 1983 powtórnie aresztowany. Zwolniony 22 VII 1983 na mocy amnestii. Kolporter: „Tygodnika Wojennego”, „Tygodnika Mazowsze”, współpracownik wydawnictw: NOWa, Krąg, CDN, Głos. W maju 1984 ciężko pobity przez nieznanych sprawców. W 1985 współorganizator podziemnych wydawnictw Mysia 5 i In Plus. W latach 1985-1989 współpracownik „CDN Głos Wolnego Robotnika”. Od 1985 przywoził z Francji (m.in. od Jerzego Giedroycia) pieniądze na działalność wydawnictw podziemnych. Współpracownik wydawnictwa Most (w 1988 współzałożyciel z Tomaszem Cyngotem Wydawnictwa PoMost). W 1990 współzałożyciel Polskiej Izby Książki i Porozumienia Wydawców Książki Historycznej. W latach 1990-1992 wiceprezes Zarządu Fundacji Pomocy 
14 stycznia 1997

\section{[4]}

Szanowny Panie Pułkowniku,

Dziękuję za list z 12-go grudnia br., który dopiero dzisiaj otrzymałem, na skutek zatorów na poczcie polskiej i francuskiej.

Bardzo dziękuję za uzupełnienie naszych braków w „Wojskowym Przeglądzie Historycznym”. Właśnie otrzymałem również wiadomość od Marka Krawczyka, że numery otrzymał.

Jak najchętniej zgadzam się na wymianę naszych pism. Wysyłam jednocześnie nr 118 „Zeszytów Historycznych”.

Łączę wyrazy poważania Redaktor KULTUURY

(Jerzy Giedroyc)

Bibliotekom Polskim. W okresie 1992-1995 dyrektor Oficyny Wydawniczej PoMost. Inicjator i współzałożyciel Towarzystwa Opieki nad Archiwum Instytutu Literackiego w Paryżu (prezes Zarządu 1995-2010). W latach 1999-2000 doradca ministra kultury i dziedzictwa narodowego. W 2003 współzałożyciel Stowarzyszenia Wolnego Słowa; M. Łątkowska, A. Borowski, Krawczyk Marek [w:] Encyklopedia „Solidarności”, t. 1: Opozycja w PRL 1976-1989, red. M. Łątkowska, Warszawa-Katowice 2010, s. 224-225; http://www.kulturaparyska.com/ pl/ludzie/pokaz/k/marek_krawczyk (dostęp 24 X 2019). 


\section{Bibliografia}

\section{Archiwalia}

Archiwum Wojskowe w Nowym Dworze Mazowieckim

Akta Wojskowej Akademii Politycznej im. Feliksa Dzierżyńskiego z lat 1951-1990

Centralne Archiwum Wojskowe Wojskowego Biura Historycznego

Kolekcja Teczek Akt Personalnych

\section{Opracowania}

W poszukiwaniu innej historii: antologia tekstów opublikowanych na łamach periodyków Instytutu Literackiego w Paryżu, red. R. Stobiecki, S. M. Nowinowski, współpr. A. Brzezińska, M. Przybysz, Łódź-Paryż 2015.

Łątkowska M., Borowski A., Krawczyk Marek [w:] Encyklopedia „Solidarności”, t. 1:

Opozycja w PRL 1976-1989, red. M. Łątkowska, Warszawa-Katowice 2010.

\section{Materiały internetowe}

Archiwum Instytutu Literackiego, Korespondencja Redakcji, teczka 916, http://static.kulturaparyska.com/attachments/25/97/5e820cd09e101c897b88a29fe30b1a0fe481c03c.jpg (dostęp 24 X 2019).

http://www.kulturaparyska.com/pl/ludzie/pokaz/k/marek_krawczyk (dostęp 24 X 2019).

\section{STRESZCZENIE}

\section{Michał Kozłowski, Jerzy Giedroyc i czasopisma wojskowe PRL}

W latach 1996-1997 trwała krótka wymiana korespondencji pomiędzy Jerzym Giedroyciem a „Wojskowym Przeglądem Historycznym”. Przyczyną korespondencji było pozyskanie dla Instytutu Literackiego w Maisons-Laffitte brakujących numerów „Wojskowego Przeglądu Historycznego”. Niniejszy artykuł zawiera opracowanie owej korespondencji wraz z krótkim omówieniem tła.

Słowa kluczowe: Jerzy Giedroyc, Wojskowy Przegląd Historyczny, Paryska Kultura, Centralna Biblioteka Wojskowa

\section{SUMMARY}

\section{Michał Kozłowski, Jerzy Giedroyc and the Military Journals in the Polish People's Republic - a summary}

In 1996-1997 Jerzy Giedroyc briefly corresponded with the „Military Historical Review”. The reason behind it was to obtain the missing issues of the „Military Historical Review" for the Institute of Literature in Maisons-Laffitte. This article contains a study of this correspondence along with an outline of its background. 
Keywords: Jerzy Giedroyc, Military Historical Review, the Parisian „Culture” („Kultura”), Central Military Library

\section{PEЗЮME}

\section{Михал Козловский, Ежи Гедройц и военные журналы в Польской Народной Республике}

В 1996-1997 гг. между Ежи Гедройцем и „Военно-историческим обозрением" произошел короткий обмен корреспонденцией. Поводом для переписки послужило получение Литературным институтом в Мезон-Лафитте недостающих номеров «Военно-исторического обозрения». Данная статья содержит анализ этой корреспонденции вместе с кратким изложением ее контекста.

Ключевые слова: Ежи Гедройц, „Военно-историческое обозрение”, „Парижская культура”, Центральная военная библиотека 